\title{
Primary B-cell Lymphoblastic Lymphoma of the Ovary
}

Sir,

An 18-year-old unmarried girl presented with a 1-month history of lower abdominal pain without fever, loss of weight or appetite, or menstrual irregularity. At a local hospital, computerised tomography imaging showed a large left adnexal mass measuring $10.6 \mathrm{~cm} \times 7.1 \mathrm{~cm} \times 8.2 \mathrm{~cm}$, for which she underwent laparotomy and ovariectomy and came to us for further management. On evaluation, she had an Eastern Cooperative Oncology Group (ECOG) performance status of one with unremarkable general physical and abdominal examination. The ovariectomy specimen reviewed at our center showed high-grade non-Hodgkin's lymphoma (NHL) confirmed as B-lymphoblastic lymphoma by immunohistochemistry [Figures 1-5]. The malignant cells were positive for LCA, CD20, C79a, CD10, and TdT and negative for staining with LMO, EMA, CD3, and CD68. The Ki-67 was strongly expressed in over $90 \%$ of the cells [Figures 1-5]. Serum alpha-fetoprotein $(2.09 \mathrm{ng} /$ $\mathrm{ml})$, beta-human chorionic gonadotropin $(2.39 \mathrm{mIU} / \mathrm{ml})$, and lactate dehydrogenase levels $(381 \mathrm{U} / \mathrm{L})$ were normal. Her baseline hemogram and peripheral smear were normal, and there was no evidence of tumor lysis. Imaging at our center showed no residual tumor in the abdomen. Bone marrow aspiration, bone marrow trephine biopsy, and cerebrospinal fluid analysis were negative for disease involvement. She started systemic therapy as per the Berlin Frankfurt Munster-95 acute lymphoblastic leukemia protocol and remains disease free 2 years after diagnosis.

Ovarian involvement by NHL is rare but is reported to occur either primarily or secondarily. ${ }^{[1,2]}$ Primary ovarian lymphoma (POL) accounts for $1.5 \%$ of all ovarian cancers and $0.5 \%$ of all NHLs. ${ }^{[2,3]}$ The pathogenesis is poorly understood, but the tumor may arise from B- and T-lymphocytes which are found in the ovarian cortex, follicles, or stroma ${ }^{[4]}$ As per the criteria proposed by Fox et al., ovarian lymphoma is considered to be primary when the tumor burden is confined to the ovary with or without direct lymph nodal infiltration in the adjacent region. ${ }^{[5]}$ Based on this, we diagnosed our patient to have POL.

Most POLs are bilateral and appear homogeneous on imaging. ${ }^{[6]}$ This feature along with the lack of ascites helpful to distinguish them from epithelial ovarian tumors in presurgical scans. ${ }^{[6]}$ There is no consensus on the optimal staging schema for POLs. Both the Ann Arbor and the International Federation of Gynaecology and Obstetrics staging approaches have been used. The major prognostic factors reported are stage at presentation, bilateral versus unilateral disease, tumor size, and International Prognostic Index score $>2$ and histological subtype. ${ }^{[7]}$ 


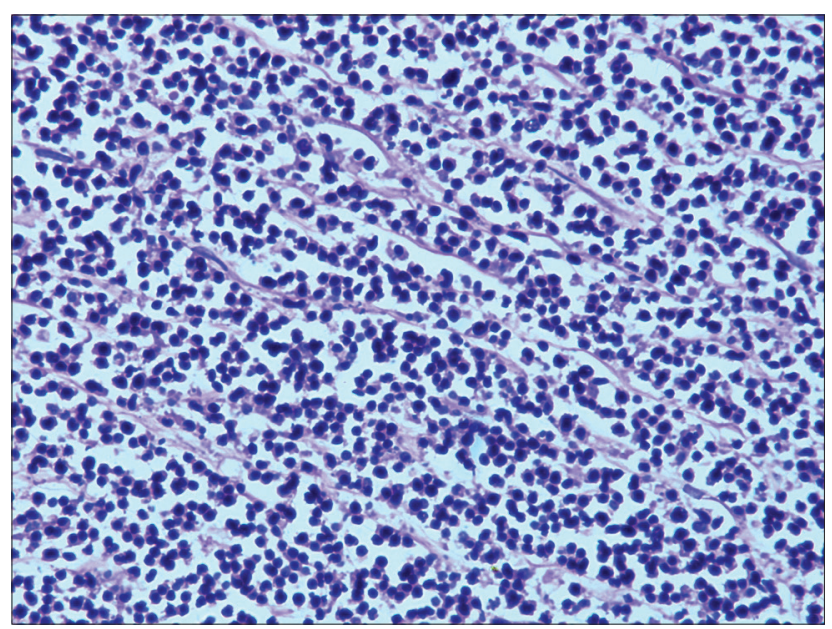

Figure 1: Sheets of atypical lymphoid cells (H and E, $\times 400)$

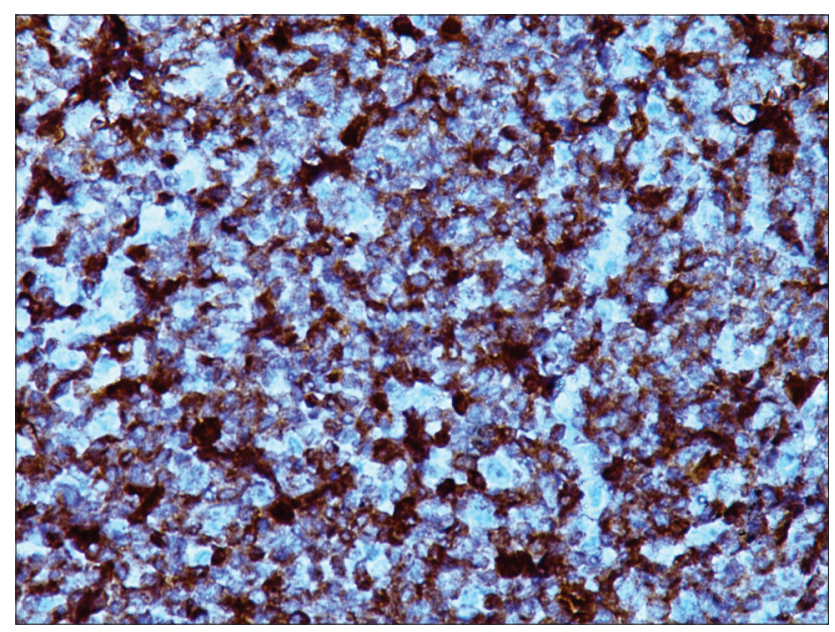

Figure 3: Atypical cells show positive reaction for CD79a (DAB, ×400)

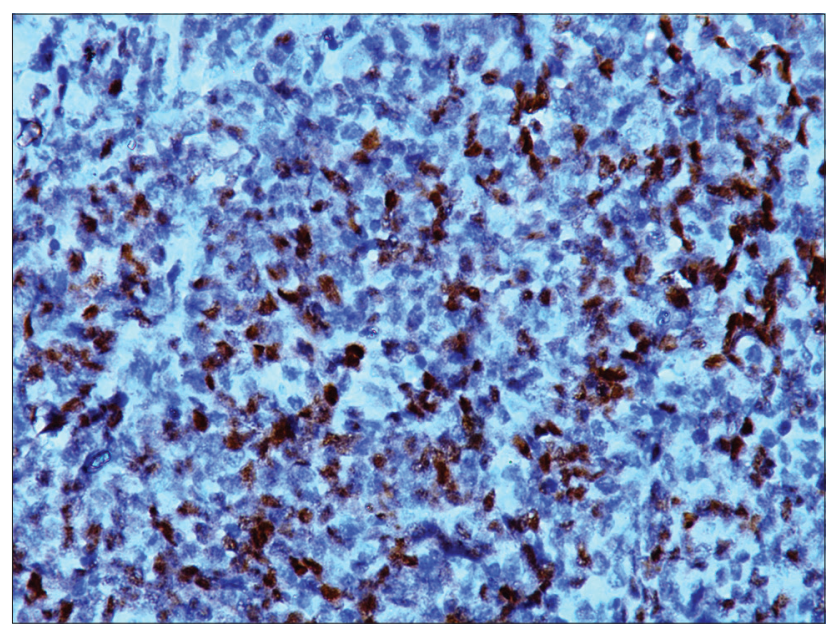

Figure 5: Atypical cells show positive reaction for TdT (DAB, ×400)

Among POLs, lymphomas of B-cell origin are the most common with Burkitt's lymphoma and diffuse large B-cell lymphoma accounting for the majority. ${ }^{[4,8-10]}$ Primary lymphoblastic lymphoma of the ovary is uncommon but has been reported in the pediatric and adolescent

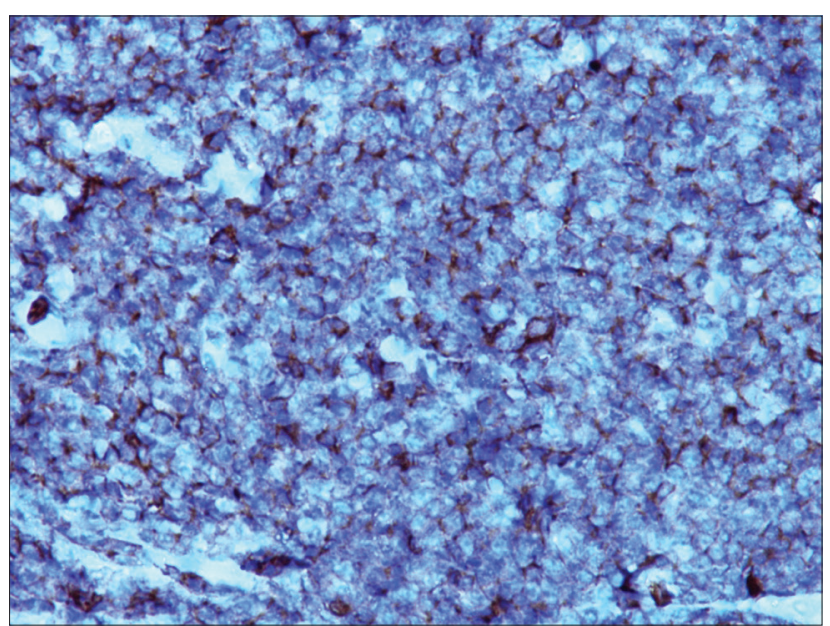

Figure 2: Atypical cells show positive reaction for CD45 (DAB, ×400)

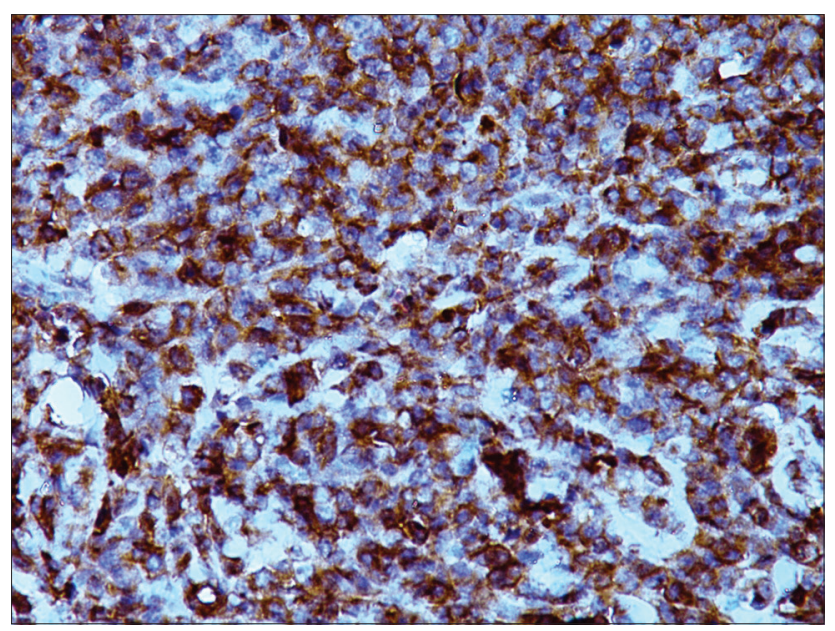

Figure 4: Atypical cells show positive reaction for CD10 (DAB, ×400)

age groups. ${ }^{[11-13]}$ Acute lymphoblastic leukemia which is biologically similar to lymphoblastic lymphoma has also been reported to involve the ovaries at relapse and can mimic epithelial cancers of the ovary. ${ }^{[14]}$

This case is being reported for its rarity and to highlight the importance of accurate histopathology in the diagnosis and management of primary ovarian neoplasms. Furthermore, we would like to highlight the possibility of POL in younger patients who present with homogeneous bilateral ovarian masses, without ascites, with normal serum tumor markers and to stress on the requirement for a preoperative biopsy of such ovarian mass lesions. This approach will be effective in preventing unwarranted major surgical resections and thus preserving fertility in such patients; the majority of whom are young and belong to the reproductive age group, as these tumors are exquisitely chemosensitive with good outcomes when treated with chemotherapy alone.

Financial support and sponsorship

Nil. 


\section{Conflicts of interest}

There are no conflicts of interest.

\section{Anjana Joel, \\ Prasanth Ganesan, Shirley Sundersingh ${ }^{1}$, Venkatraman Radhakrishnan, Trivadi S Ganesan, Tenali Gnana Sagar}

Departments of Medical Oncology and ${ }^{\prime}$ Oncopathology, Cancer Institute (WIA), Chennai, Tamil Nadu, India

Address for correspondence:

Dr. Prasanth Ganesan,

Department of Medical Oncology, Cancer Institute (WIA), Chennai,

Tamil Nadu, India.

E-mail:pg1980@gmail.com

\section{References}

1. Chorlton I, Norris HJ, King FM. Malignant reticuloendothelial disease involving the ovary as a primary manifestation: A series of 19 lymphomas and 1 granulocytic sarcoma. Cancer 1974;34:397-407.

2. Senol T, Doger E, Kahramanoglu I, Geduk A, Kole E, Yucesoy I, et al. Five cases of non-hodgkin B-cell lymphoma of the ovary. Case Rep Obstet Gynecol 2014;2014:392758.

3. Dimopoulos MA, Daliani D, Pugh W, Gershenson D, Cabanillas F, Sarris AH. Primary ovarian non-Hodgkin's lymphoma: Outcome after treatment with combination chemotherapy. Gynecol Oncol 1997;64:446-50.

4. Vang R, Medeiros LJ, Fuller GN, Sarris AH, Deavers M. Non-Hodgkin's lymphoma involving the gynecologic tract: A review of 88 cases. Adv Anat Pathol 2001;8:200-17.

5. Fox H, Langley FA, Govan AD, Hill AS, Bennett MH. Malignant lymphoma presenting as an ovarian tumour: A clinicopathological analysis of 34 cases. Br J Obstet Gynaecol 1988;95:386-90.

6. Ferrozzi F, Catanese C, Uccelli M, Bassi P. Ovarian lymphoma. Findings with ultrasonography, computerized tomography and magnetic resonance. Radiol Med 1998;95:493-7.

7. Zhao XY, Hong XN, Cao JN, Leaw SJ, Guo Y, Li ZT, et al. Clinical features and treatment outcomes of 14 cases of primary ovarian non-Hodgkin's lymphoma: A single-center experience. Med Oncol 2011;28:1559-64.

8. Monterroso V, Jaffe ES, Merino MJ, Medeiros LJ. Malignant lymphomas involving the ovary. A clinicopathologic analysis of 39 cases. Am J Surg Pathol 1993;17:154-70.

9. Vang R, Medeiros LJ, Warnke RA, Higgins JP, Deavers MT. Ovarian non-Hodgkin's lymphoma: A clinicopathologic study of eight primary cases. Mod Pathol 2001;14:1093-9.

10. Sun J, Zhang J, Ling Q, Luo Y, Wu S, Liang Z, et al. Primary diffuse large B-cell lymphoma of the ovary is of a germinal centre B-cell-like phenotype. Virchows Arch 2015;466:93-100.

11. Sakurai N, Tateoka K, Taguchi J, Terada T. Primary precursor B-cell lymphoblastic lymphoma of the ovary: Case report and review of the literature. Int J Gynecol Pathol 2008;27:412-7.

12. Iyengar P, Ismiil N, Deodhare S. Precursor B-cell lymphoblastic lymphoma of the ovaries: An immunohistochemical study and review of the literature. Int J Gynecol Pathol 2004;23:193-7.

13. Yadav R, Sharma MC, Karak AK, Agarwal N, Kumar R, Kumar L. Natural history of primary precursor B lymphoblastic lymphoma of the ovary: Report of a rare case. J Obstet Gynaecol Res 2013;39:611-6.

14. Singhal MK, Krishnan V, Singh S, Kumar R, Raina V. Isolated ovarian relapse in a 68 -year-old woman with acute lymphoblastic leukemia. J Clin Oncol 2010;28:e73-4.

This is an open access journal, and articles are distributed under the terms of the Creative Commons Attribution-Non Commercial-ShareAlike 4.0 License, which allows others to remix, tweak, and build upon the work non-commercially, as long as appropriate credit is given and the new creations are licensed under the identical terms.

\begin{tabular}{|l|l|}
\hline \multicolumn{2}{|c|}{ Access this article online } \\
\hline Quick Response Code: & Website: \\
& www.ijmpo.org \\
\cline { 2 - 3 } & DOI: \\
\hline
\end{tabular}

How to cite this article: Joel A, Ganesan P, Sundersingh S, Radhakrishnan V, Ganesan TS, Sagar TG. Primary B-cell lymphoblastic lymphoma of the ovary. Indian J Med Paediatr Oncol 2018;39:418-20.

C 2018 Indian Journal of Medical and Paediatric Oncology | Published by Wolters Kluwer - Medknow 